\title{
The Positive Effects of a Combined Program of Creative Dance and BrainDance on Health-Related Ouality of Life as Perceived by Primary School Students
}

Authors' contribution:

A) conception and design of the study

B) acquisition of data

C) analysis and interpretation of data

D) manuscript preparation

E) obtaining funding

\author{
Theocharidou Olga ${ }^{1 \mathrm{~A}-\mathrm{E}}$, Lykesas Georgios ${ }^{1}$ A-E , Giossos \\ Ioannis $^{2}$ A-E , Chatzopoulos Dimitrios ${ }^{1 \text { A-E }}$, \\ Koutsouba Maria ${ }^{2}$ A-E \\ ${ }^{1}$ School of Physical Education and Sport Science, Aristotle University of \\ Thessaloniki, Greece \\ ${ }^{2}$ School of Physical Education and Sport Science, National and Kapodistrian \\ University of Athens, Greece
}

The combination of Creative Dance and BrainDance within the context of physical education could be a promising innovation. This combined program can be implemented in primary school to help students achieve a better and more holistic assessment of their Health-Related Quality of Life (HRQoL), covering aspects of physical, emotional, social, and mental functioning and well-being. The aim of this study was to investigate the impact that a combined Creative Dance and BrainDance program based on the Laban Theory of Movement Analysis has on HRQoL perceptions of primary school students when this program is implemented within the context of the physical education curriculum in primary school. For this purpose, an eight-week educational intervention was designed combining Creative Dance and BrainDance into one single program.

The survey sample consisted of 32 fifth- and sixth-grade primary school students. The Kidscreen-52 questionnaire was used to collect data. Data analysis was performed with the use of descriptive statistical indices and mixed analysis of variance (ANOVA). Although the results showed no differences between the beginning and end of the educational intervention, a fact that might be due to the small sample and the time of the implementation of the program (limited to 8 weeks), its implementation produced very good results with regard to improvisation, body control, balance, and coordination, as well as kinaesthetic awareness and musical rhythmic skills. Creative Dance and BrainDance promote imagination, creativity, improvisation, and self-esteem in general, particularly in primary school students.

creative dance, BrainDance, health-related quality of life, primary education

\section{Introduction}

Dance can be defined as a multidimensional, unique experience that contributes decisively to the individual's integrated development, educating them in a way that combines feelings and emotions with logic and practical motor skills (Sanderson 2001). Many researchers believe that dance promotes the healthy 
development of self-image, body awareness, self-esteem, and self-control (Karff 1969; Joyce 1980; Hanna 1988; Adshead et al. 1998; Stinson 1998). Body awareness is considered to be an essential requirement for one to get familiar with their feelings and body, and actually constitutes the first step towards the development of behavioral self-control (Hanna 1988; Stinson 1998). Dance can be used as a means to express and communicate ideas, interpret sensory impressions, and experience feelings of joy and positive moods expressed symbolically in body movement forms (Dimondstein 1971). For all the above reasons, dance constitutes a particular component of the physical education curriculum in primary school in many countries all over the world as a holistic approach to developing body movement, expressiveness, and creativity (Stinson 1988; Bergmann 1995; Miller 2007; House, Éireann, Foster \& Cliath 2009).

A special form of dance is "Creative Dance," combining the knowledge of movement with the art of expression (Bergmann 1995; Gilbert 2015). It also features the basis and starting point for Contemporary Dance, Modern Dance, and Theatre Dance or Art Dance. BrainDance is not a form of dance; it is actually an excellent form of physical exercise that can be used either as a warm-up or as main sequential exercises for all ages at all learning levels, teaching students how to align the body, reorganize the central nervous system, develop focus and concentration, enhance social skills, and release stress (Gilbert 2015). Combining BrainDance with Creative Dance within the context of physical education could be a promising innovation. However, there are rare references to the combination of Creative Dance with BrainDance (Gilbert 2015). Although there are several theories concerning the positive benefits of dance for children (Dimondstein 1974; Best 1985; Mac Donald 1991; Davis 1995; Gilbert et al. 2006; Swindlehurst \& Chapman 2008; Gilbert 2015), there is unfortunately a lack of research concerning the effects of Creative Dance (Lobo \& Winsler 2006; Lykesas \& Zachopoulou 2006; Quin, Frazer, \& Redding 2007; Tyrovola 2012; Savrami 2012; Bungay \& Vella-Burrows 2013; Tsompanaki 2014).

This study was carried out to investigate the impact of the combination of Creative Dance and BrainDance on physical education in the school setting, and more specifically on Health Related Quality of Life (HRQoL) as perceived by students themselves. HRQoL is defined as a sector of Quality of Life (QoL) focusing on the assessment of physical/psychological health and social well-being (Zhao \& Badler 2001; Mooney 2006; Lykesas et al. 2018). In particular, the aim of this survey was to investigate the impact that a combined Creative Dance and BrainDance program based on the Laban Theory of Movement Analysis (Laban 1975) has on HRQoL self-perceptions of primary school students when this program is implemented within the context of physical education.

\section{Creative Dance \& BrainDance in Physical Education}

Creative, modern, or expressive dance can serve as:

a) a means for the creative development and aesthetic cultivation of students within the context of physical education (Tyrovola 1989; Kraus et al. 1991; Lachapelle, Murray, \& Neim 2003; Koutsouba 2004; Pedagogical Institute 2011),

b) an art-related subject within the context of Art Theory and History,

and

c) a teaching topic at various dance institutes, schools, academies, and universities (Barmpousi 2004; Gkousdova \& Koutsouba 2006; Lai Keun \& Hunt 2006; Tyrovola \& Koutsouba 2007).

Stinson (1988) supports that Creative Dance (or Creative Movement) is the form of dance that optimally meets children's multiple needs and is particularly suitable for small elementary school students since it is a form of art based on physical movement and not on the movement of a particular dance style such as ballet or traditional dances (Stinson 1988; Lykesas et al. 2009, 2014). Also, according to Bergmann (1995), Creative Dance is easy to teach at elementary schools because, unlike other forms of dance, it does not require years of previous practice (Bergmann 1995).

Yet, as the Irish National Teachers' Organization (2009) has reported within the context of a European survey, dance and drama are not integrated as elements in the school curricula of Europe. In fact, Ireland is the only European country that integrates Creative Dance in its school curriculum (Irish National Teachers' Organization 2009), while on a worldwide level Creative Dance is implemented at schools in the United States 
(Baltimore County Public Schools 2012) and Taiwan (Wu et al. 2012). In most countries around the world, Creative Dance still remains an art form familiar only to talented or wealthy people, and lessons are usually provided in private studios and extremely rarely at public schools as educational programs. Greece is no exception. There are only a few studies concerning the significance of Creative Dance in physical education at schools (Savrami 2012; Tsompanaki 2014). The reason that dance programs have not yet been developed for all levels of school education in Europe, the United States, and the rest of the world has to do with the debate over whether students need to be taught movement more as a form of art (dance), practical body training (physical education), or a means to teach other subjects (dance integration).

However, there is a general consensus that there are benefits that come along with engaging in Creative Dance (Ward 1974; Sherborne 1990; Stinson 1998; Swindlehurst \& Chapman 2008). In terms of these benefits, Davis (1995) argues that Creative Dance provides a variety of motor skills, promotes cooperation, leadership, and critical thinking, and creates a supportive environment that recognizes the uniqueness of each child. In the same vein, Best (2005) claims that students can learn to express their inner world through the art of dance and thus experience and feel the physical, mental, and emotional benefits, allowing them to investigate and compare social issues on their own personal terms. In his research, Mac Donald (1991) confirms that dance constitutes a "vehicle for physical, emotional, intellectual, social development and facilitates the balance between the children's inner and outer world." Finally, Lykesas and Zachopoulou (2006) have demonstrated that a Music/Education program integrating elements of Creative Dance increased pleasure and improved intrinsic motivation for the increased participation of primary school students.

BrainDance is a series of eight developmental movement patterns that healthy babies naturally go through during the first year of life and that wire the human body with the brain (Hackney 2003; Bloom 2006; Gilbert et al. 2006; Billingham 2009; Shusterman 2012; Gilbert 2015). In particular, these movement patterns activate the body from its center to the extremities (upper/lower body, right/left side, head/tail, cross-lateral, breathing, tactile, core-distal/spine, vestibular movements), with all respective benefits for the body (Hackney 2003; Gilbert 2015). BrainDance can be used as a warm-up or as main sequential exercises for all ages and learning levels. It constitutes part of Laban's theory of Human Movement Analysis and owes its existence to Laban's collaborator Irmgard Bartenieff (1890-1981), who, based on the above theory, created a set of eight movement patterns known as the "Bartenieff Fundamentals" (Guest 1977; Groff 1995; Hackney 2003; Billingham 2009; Theocharidou 2017). In 2015, influenced by Rudolf Laban's four movement categories, Gilbert formed her own movement vocabulary and proposed a BrainDance program integrating the four fundamental elements of Creative Dance (Body, Space, Time, Force/Dynamics) and the fifteen dance concepts (Body: parts, shapes, relationships, balance; Space: place, size, level, direction, pathway, focus; Time: speed, rhythm, duration; Force/Dynamics: energy, weight, flow).

\section{Health-Related Quality of Life}

During the last two decades, there has been high international interest in the concept of Quality of Life (QoL) and its measurement methods. According to the World Health Organization (WHO), the QoL concept integrates every individual's perception of their position in life within the context of the culture and value system in which they live in relation to their goals, standards, expectations, desires, and concerns (WHOQOL Group 1998). Dalkey and Rourke (1973) perceive QoL as a sense of well-being and happiness, while Pavot and Dienar (1991) define it as the subjective feeling of life satisfaction based on one's own internal standards or criteria. In any case, the multiple approaches to the concept of QoL from the perspective of economic, social, psychological, and medical sciences (Yfantopoulos 2001, 2007; Petraki \& Koutsouba 2013; Theocharidou 2017; Venetsianou \& Koutsouba 2017; Lykesas et al. 2018) justify the great number of different definitions and have succeeded in highlighting both the objective (socio-economic indicators) and subjective dimension (individual perceptions) of QoL (Ikonomou et al. 2001; Cummins 2005). As perceived within the context of human health, QoL comprises a great variety of features related to humans' overall physical and psychological health (Chodzko-Zajko 2005). Therefore, the term "Health-Related Quality of Life" (HRQoL) has been introduced, which has to do with the assessment of health in its broader sense (Chen et al. 2005). 
HRQoL is characterized as a sector of QoL focusing on the evaluation of physical and psychological health and social well-being (Mooney 2006). Kaplan and Bush (1982) distinguished three fundamental aspects within the concept of HRQoL:

a) the subjective perception of an individual's functional condition (physical and psychological status);

b) the functional effects of an individual's health condition, and

c) functional limitations in the areas that are essential for the individual to achieve his/her desired goals in life.

According to Theodoropoulou et al. (2012), there are both general and specific questionnaires for the measurement of HRQoL. The most valid and reliable questionnaires for adults are the SF-36 Health Review (Ware et al. 1998) and Nottingham Health Profile, which have been translated into Greek and several other languages (Vidalis et al. 2002). The most reliable questionnaire for the assessment of children's HRQoL is the Kidscreen-52 questionnaire (Kidscreen Group Europe 2006).

\section{Methodology}

Subjects

The study sample comprised 32 fifth- and sixth-graders, aged 10 to 12 years old, who attended a primary school located in a semi-urban district.

\section{Intervention}

The intervention program of the survey was implemented within the context of the second school term of the year 2016-2017. It lasted 8 consecutive weeks, with 15 teaching hours performed twice a week, according to the students' school timetable (7 weeks x 2 hours per week +1 hour). Every Creative Dance lesson lasted 45 minutes and was designed for fifth- and sixth-grade primary school students aged 10 to 12 years old. The intervention program aimed at developing:

a) critical thinking through problem solving, observation, and reflection;

b) physical well-being and creative movement by exploring the concepts of dance, improvisation, and choreography;

c) social skills through collaboration within small groups of students; and d) psychological well-being by reinforcing self-perception, general mood, and emotions.

The program was designed based on Laban's movement elements (body, space, time, dynamic movement, and relationships) as adapted by Gilbert (2015) into body, space, time, and dynamics/force. Following an active learner-centered teaching method, the specific Creative Dance program that was implemented was based on the combination of two teaching styles:

a) Guided Discovery and

b) Divergent Production as defined by Mosston and Ashworth (2008).

The two abovementioned teaching styles enhanced the students' creativity (Derri \& Pachta 2007; Lykesas et al. 2010, 2014) and are consistent with the philosophy and implementation of Creative Dance programs as expressed in the Laban Theory of Movement Analysis (Lykesas 2002; Koutsouba 2005; Pedagogical Institute 2006; Lykesas \& Koutsouba 2008).

\section{Measurement Instrument}

The Kidscreen-52 Questionnaire (Kidscreen Group Europe 2006), which is widely recognized throughout Europe, was used to measure the perceptions of the participants about their HRQoL (RavensSiebereretal 1998; Tountas \& Tsiantis 2005; Ottova et al. 2012; Olweus 2013; Theocharidou 2017). The Kidscreen-52 Questionnaires are a family of self-referral tools that aim at assessing the well-being and HRQoL of children and adolescents ( 8 to 18 years old) who are healthy or suffer from chronic diseases and have different nationalities and cultural origins. The Kidscreen-52 Questionnaire (the complete version takes 15-20 min. to fill in) covers the following ten domains:

1. Physical Activities \& Health (related to physical well-being: physical health, activity, fitness and energy at home, school, games, sports) (5 items), 
2. Emotions (related to psychological well-being: positive perceptions, feelings of joy and pleasure, life satisfaction) (6 items),

3. General Mood (related to moods and emotions: experience of depressive moods and stressful feelings such as grief, loneliness, sorrow, low self-esteem, etc.) (7 items),

4. Self-Perception (related to self-image: positive or negative body image through self-perception and third-party assessment of oneself) (5 items),

5. Leisure Time (focuses on the opportunities offered to children/teenagers to create their own time for social relations and entertainment) (5 items),

6. Family \& Home Life (6 items),

7. Friends (related to friends and social support: quality of social relationships with friends and peers, perception of social support, creation/preservation of friendship, acceptance, respect, support, communication) (6 items),

8. School \& Learning (related to school and learning: perception of cognitive ability with regard to learning, concentration, and general feelings about school, i.e., satisfaction from school performance and abilities, student-teacher relationships, etc.) (6 items),

9. Self \& Others (related to school bullying: feelings of acceptance or rejection) (3 items), and

10. Financial Resources (assesses the children's/adolescents' own perceptions of their financial resources as to whether they feel they have the required economic opportunities to live in a way that is comparable to their peers) (3 items).

In this survey, the collected data were related to seven dimensions, namely:

a) Physical Activities \& Health,

b) Emotions,

c) General Mood,

d) Self-Perception,

e) Friends,

f) School \& Learning,

g) Self \& Others.

The Kidscreen-52 dimension scores were calculated with the use of the Rasch rating scales, which were selected since they meet the model's requirements: uni-dimensionality of questions, homogeneity of questions and participants, sufficiency of overall score. In this survey, no data were collected for the dimensions "Financial Resources," "Family \& Home Life," and "Leisure" because these three dimensions are not related to the benefits of Creative Dance and therefore did not relate to this research.

\section{Research approach}

The study was designed following a quasi-experimental approach. Although there was a lack of random sampling, different domains were investigated under real, inartificial circumstances. The quasi-experimental design resulted in high external validity but low internal validity.

\section{Statistical analysis}

The statistical data were analyzed with the use of a) descriptive statistical indices (mean values and standard deviations) and b) mixed ANOVA to investigate differences by measurement and gender (Thomas et al. 2003).

\section{Results}

Sixteen fifth-graders and sixteen sixth-graders, all primary school students, participated in the survey. With regard to gender, there were sixteen boys and sixteen girls. As for age, two students were 10 years old, thirteen students were 11 years old, and seventeen students were 12 years old.

Table 1 shows the values of Cronbach's $\alpha$ consistency index for all dimensions in both measurements. 
Table 2 shows the mean values and standard deviations of all dimensions in both measurements.

Table 3 shows the results of mixed ANOVA for differences in terms of gender. No gender interaction or gender differences were found. "General Mood" and "School \& Learning" were the only dimensions that presented statistically significant improvement in the second measurement

Table 1. Cronbach's $\alpha$ consistency index for all dimensions

\begin{tabular}{lcc}
\hline & $\begin{array}{c}\text { Cronbach's } \alpha \\
\left(1^{\text {st }} \text { measurement }\right)\end{array}$ & $\begin{array}{c}\text { Cronbach's } \alpha \\
\left(2^{\text {nd }} \text { measurement }\right)\end{array}$ \\
\hline Physical Activities \& Health & 0.72 & 0.65 \\
Emotions & 0.78 & 0.75 \\
General Mood & 0.65 & 0.66 \\
Self-Perception & 0.60 & 0.60 \\
Friends & 0.68 & 0.64 \\
School \& Learning & 0.70 & 0.69 \\
Self \& Others & 0.69 & 0.70 \\
\hline
\end{tabular}

Source: Own Study.

Table 2. Mean values and standard deviations of all dimensions in both measurements.

$\begin{array}{lllll} & \text { Min } & \text { Max } & M & S D \\ \text { Physical Activities \& Health (1 } 1^{\text {st }} \text { measurement) } & 2.25 & 5.00 & 4.07 & 0.64 \\ \text { Physical Activities \& Health (2 }{ }^{\text {nd }} \text { measurement) } & 1.75 & 5.00 & 4.06 & 0.75 \\ \text { Emotions (1 } 1^{\text {st }} \text { measurement) } & 3.00 & 4.83 & 4.07 & 0.57 \\ \text { Emotions (2 }{ }^{\text {nd }} \text { measurement) } & 2.67 & 5.00 & 4.26 & 0.59 \\ \text { General Mood (1 } 1^{\text {st }} \text { measurement) } & 2.14 & 4.86 & 4.08 & 0.54 \\ \text { General Mood (2 }{ }^{\text {nd }} \text { measurement) } & 2.43 & 5.00 & 4.33 & 0.46 \\ \text { Self-Perception (1 } 1^{\text {st }} \text { measurement) } & 2.60 & 5.00 & 4.26 & 0.55 \\ \text { Self-Perception (2 } 2^{\text {nd }} \text { measurement) } & 1.80 & 5.00 & 4.41 & 0.62 \\ \text { Friends (1 } 1^{\text {st }} \text { measurement) } & 1.83 & 4.83 & 3.75 & 0.75 \\ \text { Friends (2 } 2^{\text {nd }} \text { measurement) } & 2.67 & 5.00 & 4.15 & 0.71 \\ \text { School \& Learning (1 } 1^{\text {st }} \text { measurement) } & 1.00 & 5.00 & 3.34 & 0.99 \\ \text { School \& Learning (2 } 2^{\text {nd }} \text { measurement) } & 2.50 & 5.00 & 3.85 & 0.66 \\ \text { Self \& Others (1 } 1^{\text {st }} \text { measurement) } & 2.33 & 5.00 & 4.61 & 0.52 \\ \text { Self \& Others (2 } 2^{\text {nd }} \text { measurement) } & 3.00 & 5.00 & 4.68 & 0.47\end{array}$

Source: Own Study.

Table 3. Results of mixed ANOVA for differences in terms of gender

\begin{tabular}{|c|c|c|c|}
\hline & $\begin{array}{l}\text { Differences in terms of } \\
\text { measurement }\end{array}$ & $\begin{array}{l}\text { Differences in terms of } \\
\text { gender }\end{array}$ & Interaction \\
\hline \multirow[t]{2}{*}{ Health } & & $F(1,30)=0.341, p=$ & \\
\hline & $F(1,30)=0.002, p=0.995$ & 0.564 & $F(1,30)=1.192, p=0.284$ \\
\hline \multirow[t]{2}{*}{ Emotions } & & $F(1,30)=0.048, p=$ & \\
\hline & $F(1,30)=1.261, p=0.270$ & 0.828 & $F(1,30)=4.086, p=0.052$ \\
\hline General & & $F(1,30)=0.221, p=$ & \\
\hline Mood & $F(1,30)=7.149, p=0.012$ & 0.642 & $F(1,30)=0.748, p=0.394$ \\
\hline
\end{tabular}




\section{Self-}

Perception

$F(1,30)=0.798, p=0.379$

Friends

$$
F(1,30)=3.552, p=0.069
$$

School \&

Learning

$$
F(1,30)=5.251, p=0.029
$$

Self \& Others

$$
F(1,30)=0.205, p=0.654
$$

$$
F(1,30)=1.707, p=
$$

0.201

$$
F(1,30)=0.949, p=0.338
$$

$F(1,30)=0.598, p=$

0.445

$$
F(1,30)=1.630, p=0.221
$$

$F(1,30)=0.013, p=$

0.909

$F(1,30)=1.762, p=0.194$

$F(1,30)=0.837, p=$

$0.368 \quad F(1,30)=0.821, p=0.372$

Source: Own Study.

\section{Discussion}

From the above findings, it appears that the educational intervention of the Creative Dance and BrainDance combination program has improved the students' HRQoL perceptions only for the dimensions "General Mood" and "School and Learning." The survey findings do not agree with the respective research findings of Quin, Frazer, and Redding (2007) concerning 348 students in Great Britain aged 11-14 years old. Why is it that there was an improvement only in these two specific domains and not in the others? What could that imply?

Concerning "General Mood," this specific dimension has to do with experiencing depressive and stressful feelings and situations. The improvement presented in this domain may be due to the fact that dance is compatible with emotional benefits. This is in line with Karff's research findings (1969), which support the idea that Creative Dance relieves and releases inner tension by enhancing emotional awareness and expression. Similarly, Joyce (1980) argued that Creative Dance is a means to express ideas and emotions, while Gilbert (2015) demonstrated that Creative Dance helps participants cope with emotional and cognitive challenges. Similar results were found by Zachariadou, Douka, and Alexandris (2012) and Zisi et al. (2014) in their studies demonstrating the improvement of QoL in elderly people participating in Greek traditional dance programs.

The dimension "School \& Learning" relates to competence with regard to learning, concentration, general feelings about school, satisfaction with learning skills and school performance, and student-teacher relationships. This domain has also improved significantly, likely due to the fact that dance has educational benefits. This is in line with the findings of Lai Keun and Hunt (2006), who demonstrated that Creative Dance activated mainly the bodily/kinaesthetic intelligence of first-graders in primary school. Lobo and Winsler (2006) and Lykesas, Tsapakidou, and Tsopmanaki (2014) showed that a carefully designed and organized Creative Dance program for primary school students significantly improved their basic kinaesthetic skills and overall motor behavior, enhanced their social skills, and reduced their aggressive behavior. According to Sanderson (1988), dance significantly contributes to the integrated development of children as it combines feelings and emotions with logic and motor skills. Koutsouba (2000, 2007) and Tyrovola (2012) revealed the positive effects of Creative Dance on the learning process.

On the other hand, the "Physical Activities" domain, relating to physical health, activity, fitness and vitality at home, school, games, and sports, did not improve. One possible explanation for this could be that the educational intervention followed the typical implementation of physical education curriculum, which was also geared towards improving these elements. This is also illustrated by the fact that the mean value of this dimension appears to be high from the very first measurement. This may be the reason why these findings do not agree with the findings of Dimondstein (1974), Stinson (1988), Mac Donald (1991), Davis (1995), Gilbert et al. (2006), Swindlehurst and Chapman (2008), and Gilbert (2015). In other words, this study design was different. The same argument can also be posed to explain why there are no differences in the rest of domains. Finally, another possible reason may be the fact that the educational intervention only lasted for a short period of time. 


\section{Conclusions}

This research aimed at studying the effectiveness and impact of a combined Creative Dance and BrainDance program on HRQoL as perceived by primary school students within the context of physical education. The sample of the survey was small, and therefore the results cannot be generalized. Improvement was observed in specific dimensions, and it is likely that a more extensive program with a longer duration could have produced different results. However, this improvement allows us to conclude that Creative Dance helps students cooperate and communicate with their classmates while also offering them rich social experiences. The research results have demonstrated that such an intervention combining Creative Dance and BrainDance could be successfully integrated within the context of physical education in the school setting for the reason that it also improves HRQoL perceptions related to physical activity and health, among other reasons. Besides, physical education teachers ought to constantly be aware of and seek different teaching strategies to enhance students' performance and help them achieve successful motor, cognitive, and social learning (Derri \& Pachta 2007).

\section{Suggestions}

According to the study results, it is clear how substantial the contribution of Creative Dance and BrainDance is to children's emotions and behavior in general. The combined Creative Dance and BrainDance program that was implemented within the school curriculum context seems to have contributed to the development and improvement of the students' HRQoL. Thus, it is proposed that this program be introduced into the physical education curriculum of schools. However, there is no doubt that there is a need for further research to be conducted; more specifically, there is a need for a) surveys in more than one school, b) surveys in more than one school with an experimental design, c) surveys with the use of different data collection and analysis methods, and d) longitudinal studies comparing the results of different implementation modes of such combination programs.

\section{REFERENCES}

Adshead, J., Hodgens, P., Briginshaw, V., \& Huxley, M. (2007). Dance analysis: Theory and practice. (Greek trans: V. Tyrovola \& M. Koutsouba). Athens, Greece: Pasxalidis Publications.

Baltimore County Public Schools. (2015). Office of dance education. Retrieved March 2, 2017, from https://www.bcps.org/offices/dance/curriculum-programs.html

Barmpousi, V. (2014). The art of dance in Greece in the 20th century. Athens, Greece: Gutenberg.

Bergmann, S. (1995). Creative dance in the education curriculum: Justifying the unambiguous. Canadian Journal of Education/Revue canadienne de l'education, 20(2), 156-165.

Best, D. (1985). Feeling and reason in the arts: The rationality of feeling. In P. Abbs (Ed.), The symbolic order: A contemporary reader on the arts debate (pp. 67-70). Philadelphia: The Falmer Press.

Billingham, L.A. (2009). The complete conductor's guide to Laban movement theory. Chicago, IL: GIA Publications.

Bloom, K. (2006). The embodied self: Movement and psychoanalysis. London, UK: Karnac.

Bungay, H. \& Vella-Burrows, T. (2013). The effects of participating in creative activities on the health and well-being of children and young people: A rapid review of the literature. Perspectives in Public Health, 133(1), 44-52.

Chen, T.H., Li, L., \& Kochen, M.M. (2005). A systematic review: How to choose appropriate health-related quality of life (HRQOL) measures in routine general practice? Journal of Zhejiang University Science B, 6(9), 936-940.

Chodzko-Zajko, W.J. (2005). Psychological and sociocultural aspects of physical activity for older adults. In C.J. Jones \& D.J. Rose (Eds.), Physical Activity: Instruction of Older Adults. (pp. 23-36). New Zealand: Human Kinetics.

Cummins, R.A. (2005). Moving from the quality of life concept to a theory. Journal of Intellectual Disability Research, 49(10), 699-706.

Dalkey, N.C. \& Rourke, D.L. (1973). The Delphi procedure and rating quality of life factors. In EPA, The Quality of Life Concept. Washington, DC: Environmental Protection Agency.

Davis, J. (1995). Laban Movement Analysis: A key to individualizing children's dance. Journal of Physical Education, Recreation \& Dance, 66(2), 31-33.

Derri, V. \& Pachta, M. (2007). Motor skills and concepts acquisition and retention: A comparison between two styles of teaching. RICYDE. Revista Internacional de Ciencias del Deporte, 3(9), 37-47. 
Dimondstein, G. (1971). Children dance in the classroom. New York, NY: Macmillan Publishing. Dimondstein, G. (1974). Exploring the arts with children. New York, NY: MacMillan Publishing. Gilbert, A.G. (2015). Creative dance for all ages (2nd ed.). Champaign, IL: Human Kinetics.

Gilbert, A.G. \& Rossano, A. (2006). Brain-compatible dance education. Reston, VA: National Dance Association.

Gkousdova, M. \& Koutsouba, M. (2006). Presentation of Panhellenic Students Artistic Games and art forms to them. Theatergrafies, 14, 98-105.

Groff, E. (1995). Laban movement analysis: Charting the ineffable domain of human movement. Journal of Physical Education, Recreation \& Dance, 66(2), 27-30.

Guest, A.H. (1977). Labanotation: The system of analyzing and recording movement ( $3^{\text {rd }}$ ed.). New York, NY: Theatre Arts Books.

Hackney, P. (2003). Making connections: Total body integration through Bartenieff fundamentals. London, UK: Routledge.

Hanna, J.L. (1988). Dance and stress: Resistance, reduction, and euphoria. New York, NY: AMS Press Inc.

Ikonomou, M., Kokkoni, M., Triantafillou, E., \& Christodoulou, G. (2001). Quality life and mental health. Conceptual approaches, clinical applications and evaluation. Archives of Hellenic Medicine, 18(3), 239-253.

House, V., Éireann, C., Foster, Á., \& Cliath, B. (2009). Creativity and the Arts in the Primary School. Discussion Document and Proceedings of the Consultative Conference on Education. Dublin, Ireland: Irish National Teachers' Organisation. Retrieved March 4, 2017, from https://www.into.ie/ROI/Publications/CreativityArtsinthePS.pdf

Joyce, M. (1980). First steps in teaching creative dance to children. Palo Alto, CA: Mayfield Publishing Company.

Kaplan, R.M. \& Bush, J.W. (1982). Health-related quality of life measurement for evaluation research and policy analysis. Health Psychology, 1(1), 61.

Karff, J. (1969). Dance in the urban school. Journal of Health, Physical Education and Recreation, 50, 43-44.

KIDSCREEN Group Europe. (2006). The KIDSCREEN Questionnaires - Quality of life questionnaires for children and adolescents. Handbook. Lengerich, Germany: Pabst Science Publishers. http://www.kidscreen.org

Koutsouba, M. (2004). The contribution of Greek traditional dance teaching in modern Greek multicultural society. In E. Avdikos, E. Loutzakis, \& C. Papakostas (Eds.), Dance Singles (pp. 213-226). Athens: Ellina Grammata.

Koutsouba, M. (2005). Notation of the dance movement: The passage from history of dance history. Athens, Greece: Propompos.

Kraus, R.G., Hilsendager, S.C., \& Gottschild, B.D. (1991). History of the Dance in Art and Education. Englewood Cliffs, NJ: Prentice Hall.

Laban, R. (1975). Modern educational dance. London, UK: Mac Donald and Evans.

Lachapelle, R., Murray, D., \& Neim, S. (2003). Aesthetic understanding as informed experience: The role of knowledge in our art viewing experiences. The Journal of Aesthetic Education, 37(3), 78-98.

Lai Keun, L. \& Hunt, P. (2006). Creative dance: Singapore children's creative thinking and problem-solving responses. Research in Dance Education, 7(1), 35-65.

Lobo, Y.B. \& Winsler, A. (2006). The effects of a creative dance and movement program on the social competence of head start preschoolers. Social Development, 15(3), 501-519.

Lykesas, G. (2002). The teaching process of traditional Greek dances in primary education implementing the method of music and movement education. Ph.D. Thesis, Aristotle University of Thessaloniki, Greece.

Lykesas, G. \& Zachopoulou, E. (2006). Music and movement education as a form of motivation in teaching Greek traditional dances. Perceptual and Motor Skills, 102, 552-562.

Lykesas, G. \& Koutsouba, M. (2008). The teaching of Greek traditional dance in the school education with the adoption of creative methods of teaching. Journal of Health and Sport Performance, 3, 37-49.

Lykesas, G., Koutsouba, M., \& Tyrovola, V. (2009). Creativity as an approach and teaching method of traditional Greek dance in secondary schools. Studies in Physical Culture \& Tourism, 16(2), 207-14.

Lykesas, G., Koutsouba, M., \& Tyrovola, B. (2010). Comparison of teacher and child-centred methods of teaching Greek traditional dance in primary education. International Journal of Physical Education, 3, 25-32.

Lykesas, G., Tsapakidou, A., \& Tsopmanaki, E. (2014). Creative dance as a means of growth and development of fundamental motor skills for children in first grades of primary schools in Greece. Asian Journal of Humanities and Social Studies, 2(1), 211-218.

Lykesas, G., Giosos, I., Theocharidou, O., Chatzopoulos, D., \& Koutsouba, M. (2018). The effect of a traditional dance program on health-related quality of life as perceived by primary school students. Journal of Education and Training Studies, 6(1), 97-104. 
Mac Donald, C.J. (1991). Creative dance in elementary schools: A theoretical and practical justification. Canadian Journal of Education/Revue Canadienne de l' Education, 16(4), 434-441.

Miller, J.P. (2007). The holistic curriculum. Toronto, Ontario, Canada: OISE Press.

Mooney, A. (2006). Quality of life: Questionnaires and questions. Journal of Health Communication, 11(3), $327-341$.

Mosston, M. \& Ashworth, S. (1994). Teaching physical education. New York, NY: Macmillan.

Olweus, D. (2013). School bullying: Development and some important challenges. Annual Review of Clinical Psychology, 9, 751-780.

Ottova, V., Erhart, M., Rajmil, L., Dettenborn-Betz, L., \& Ravens-Sieberer, U. (2012). Overweight and its impact on the health-related quality of life in children and adolescents: Results from the European KIDSCREEN survey. Quality of Life Research, 21(1), 59-69.

Pavot, W. \& Diener, E. (1991). A manual for the satisfaction with life scale. Urbana, IL: University of Illinois.

Pedagogical Institute. (2006). Physical education in primary school and curriculum: Book of teacher. Athens: Greek Ministry of Education and Religious Affairs.

Petraki, B. \& Koutsouba, M. (2013). Greek traditional dance as a medium promoting the positive psychology of the individual: Study review. In Proceedings of the 31st World Congress on Dance Research (pp. 1-26). Retrieved June 15, 2017, from https://docs.google.com/file/d/0B_79atJAGDeaaUgwMERPZWhHOWM dit?pli=1.

Quin, E., Frazer, L., \& Redding, E. (2007). The health benefits of creative dance: Improving children's physical and psychological wellbeing. Education and Health, 25(2), 31-33.

Ravens-Sieberer, U. \& Bullinger, M. (1998). Assessing health-related quality of life in chronically ill children with the German KINDL: First psychometric and content analytical results. Quality of Life Research, 7, 399-407.

Sanderson, P. (1988). Physical education and dance. In T. Roberts (Ed.), Encouraging expression: The arts in primary school (pp. 32-67). London, UK: Cassell.

Sanderson, P. (2001). Age and gender issues in adolescent attitudes to dance. European Physical Education Review, 7(2), 117-136.

Savrami, K. (2012). Dance in education: The Greek reality. Research in Dance Education, 13(1), 99-106.

Sherborne, V. (1990). Developmental movement for children: Mainstream, special needs and pre-school. Cambridge, UK: Cambridge University Press.

Shusterman, R. (2012). Thinking through the body: Essays in somaesthetics. Cambridge, UK: Cambridge University Press.

Stinson, S. (1988). Dance for young children: Finding the magic in movement. Reston, VA: National Dance Association/American Alliance for Health, Physical Education, Recreation.

Stinson, S. (1998). Creative dance for preschool children. Journal of Physical Education, Recreation \& Dance, 59(7), 5256.

Swindlehurst, G. \& Chapman, A. (2008). Teaching dance: A framework for creativity. In J. Lavin (Ed.), Creative approaches to physical education: Helping children to achieve their true potential (pp. 29-54). Abingdon, UK: Routledge.

Theocharidou, O. (2017). The effectiveness of a creative dance program based on the Laban theory, relating to the quality of life perceptions associated with the health of students/three in primary education. Master's thesis, Aristotle University of Thessaloniki, Greece.

Theodoropoulou, E., Karteroliotis, K., Nassis, G., Koskolou, M., \& Geladas, N. (2012). Methods of assessing healthrelated quality of life. Kinesiology, 5(1), 58-66.

Thomas, J.R. \& Nelson, J.K. (2003). Methods of research into physical activity. Athens, Greece: Paschalidis.

Tountas, G. \& Tsiantis, G. (2005). The kidscreen study: Assessing the quality of life related to the health of children and adolescents. Retrieved June 22, 2017, from http://www.neahygeia.gr/UserFiles/File/MELETH_KIDSCREEN.pdf

Tsompanaki, E. (2014). Is there a need for a higher dance institution in Greece? The reality in Greek contemporary dance institutions. Research in Dance Education, 15(3), 271-288.

Tyrovola, V. (1989). Traditional dance as a means of aesthetic treatment. Reason and Act, 39, 44-53.

Tyrovola, V. \& Koutsouba, M. (2007). Prologue. In J. Adshead (Ed.), Dance analysis: Theory and practice (pp. 17-29; Greek Trans: V. Tyrovola \& M. Koutsouba). Athens, Greece: PX Pasxalidis Publications.

Tyrovola, V. (2012). Leadership and R. Von Laban: The invisible aspects of birth of creative-expressive dance. Socialhistorical approach. Scientific Journal Kinesiology-Humanistic Direction, 5, 7-22.

Venetsianou, F. \& Koutsouba, M. (2015). The study of the dancers' physical fitness: Present state of art and future trends. Science of Dance, 8, 1-26. 
Vidalis, A.A., Syngelakis, M., Papathanasiou, M., Whalley, D., \& McKenna, S.P. (2002). The Greek version of the Nottingham Health Profile: Features of its adaptation. Hippokratia, 6(1), 79-82.

Ward, W. (1974). Creativity in young children. The Journal of Creative Behavior, 8, 101-106.

Ware, J.E., Kosinski, K.M., Gandek, B., Aaronson, N.K., Apolone, G., Bech, P., Braizer, J., Bullinger, M., Kaasa, S., Leplege, A., Prietol, L., \& Sullivan, M. (1998). The factor structure of the SF-36 Health Survey in 10 countries: Results from the IQOLA Project. Journal of Clinical Epidemiology, 51(11), 1159-1165.

WHOQOL Group. (1998). The World Health Organisation Quality of Life Assessment (WHOQOL): Development and general psychometric properties. Social Science \& Medicine, 46, 1569-1585.

Wu, Y., Tseng, C., \& Lin, M. (2012). The action of implementing creative dance in school education in Taiwan. Retrieved May 3, 2017, from http://ausdance.org.au/uploads/content/publications/2012-global-summit/teaching-dance-rp/theaction-of-implementing-creative-dance-in-school-education-in-taiwan-1.pdf

Yfantopoulos, J. (2001). Quality of life and QALYs in the measurement of health. Archives of Hellenic Medicine, 18(2), 114-130.

Yfantopoulos, J. (2007). Measurement of quality of life and European health model. Archives of Hellenic Medicine, 24(1), 6-18.

Zachariadou, Z., Douka, S., \& Alexandris, K. (2012). Investigating the relationship between the perceived quality of life and the degree of blending in a program of Greek traditional dances, Thrace, Greece. In The Proceedings of the 20th International Congress of Physical Education \& Sport, 18-20 May 2012 (pp. 3-6). Komotini, Greece.

Zhao, L. \& Badler, N.I. (2001). Laban Movement Analysis. In L. Zhao \& N.I. Badler (Eds.), Synthesis and acquisition of Laban movement analysis qualitative parameters for communicative gestures (pp. 38-43). University of Pennsylvania, PA: Penn Libraries.

Zisi, V., Gianni, A., Bougiesi, M., Pollatou, E., \& Michalopoulou, M. (2014). Systematic participation in folk dance or physical activity? Effects in quality of life in the elderly. Inquiries in Sport \& Physical Education, 12(1), 1-8. Retrieved April 3, 2017, from http://research.pe.uth.gr/emag/index.php/inquiries/article/view/146/133

\section{AUTHOR'S ADDRESS: $\quad$ Georgios Lykesas}

Aristotle University of Thessaloniki School of Physical Education and Sport Science 57001 Thermi, Thessaloniki, Greece

E-mail: glykesas@phed.auth.gr

Received: 15 February 2018; Accepted: 3 April 2018 